\title{
PLACENTAL STEROID METABOLISM IN LATE PREGNANCY
}

\author{
V.A. CRAIG \\ A.R.C. Institute of Animal Physiology, Babraham, Cambridge, UK
}

There are considerable differences between species in the contribution of the placenta to the concentration of steroids in the maternal circulation. This is particularly evident in the placental contribution to the maternal plasma concentration of progesterone, the hormone necessary for the maintenance of pregnancy. Some species depend predominantly on progesterone synthesized by the placenta for the maintenance of pregnancy, as in women (throughout the majority of gestation) and sheep (for the final two-thirds of gestation), while in other species, as in the goat and the pig, the placental contribution to maternal progesterone is relatively low and pregnancy is maintained by luteal progesterone secretion.

Changes in placental steroid metabolism have been implicated in the sequence of hormonal events in the maternal circulation which leads to the onset of labour in the goat and the sheep. In sheep these endocrine changes have been described in considerable detail (Anderson, Flint and Turnbull, 1975; Steele, Flint and Turnbull, 1976; Flint and Ricketts, 1979). However it is only in recent years that certain parallel mechanisms have become apparent in the goat. In this species, parturition occurs as a direct consequence of the cessation of luteal function which is associated with the release of uterine prostaglandin $F_{2 \alpha}$ and which results in the removal of the 'progesterone block'. As in sheep, an early step in the chain of events leading to the release of prostaglandin $F_{2 \alpha}$ is a rise in the concentration of cortisol in the foetal circulation which occurs over the last 4-10 days of pregnancy (Currie and Thorburn, 1977). This has been shown to induce the activity of the placental steroid metabolizing enzyme $17 \alpha$-hydroxylase (Flint $e t$ al., 1978) leading to the formation of increased amounts of substrate for the synthesis of oestrogens. Of the oestrogens thus formed, it has been demonstrated that oestradiol-17 $\beta$ will induce the release of uterine prostaglandin $F_{2 \alpha}$ into the uterine vein (Currie, Cox and Thorburn, 1976) thus providing an important link between the increase in foetal plasma cortisol and regression of the corpus luteum of pregnancy.

The pig is another species in which the corpora lutea are the major source of maternal progesterone and certain similarities exist between the pig and the goat in the hormonal changes occurring in both the foetal and the maternal circulation prior to parturition. In the pig, the peripheral plasma concentration of progesterone remains steady at approximately $10 \mathrm{ng} / \mathrm{ml}$ until about 48 hours prior to parturition when it declines rapidly 
(Ash et al., 1973; Robertson and King, 1974; Ash and Heap, 1975; Baldwin and Stabenfeldt, 1975). The plasma concentrations of oestrone (Figure 19.1 ) and oestradiol-17 $\beta$ start to rise on or about 108 days of gestation and then fall rapidly once delivery is completed. The fall in the plasma concentration of progesterone is also associated with the release of uterine prostaglandin $F_{2 \alpha}$ into the maternal circualtion (Nara and First, 1977; First and Bosc, 1979). Evidence has been obtained which suggests that increased foetal cortisol secretion presages the rise of oestrone and oestradiol-17 $\beta$

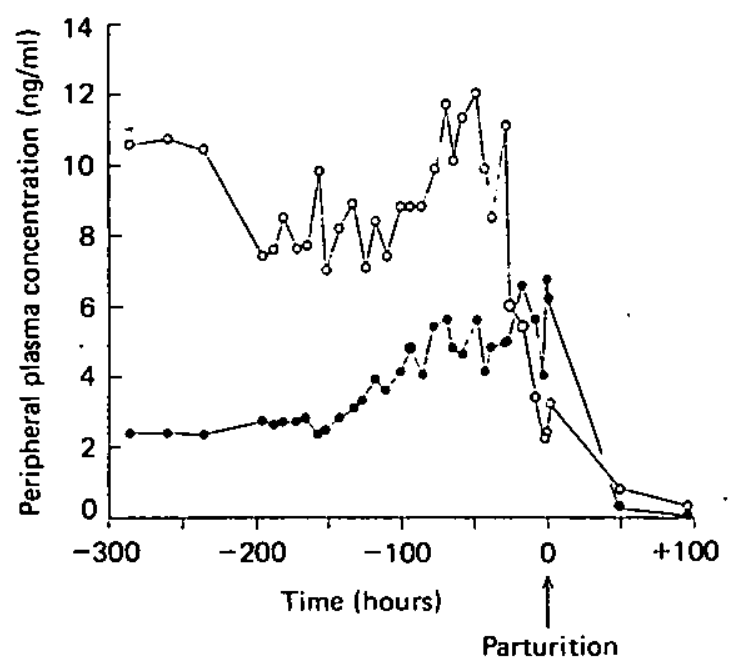

Figure 19.1 Changes in the peripheral plasma concentration of progesterone $\left(\mathrm{O}_{-}-\mathrm{O}\right)$ and oestrone (-) over the last two weeks of gestation. The data were obtained from two animals and the peripheral plasma steroid concentration is expressed in hours relative to the delivery of the first piglet

seen in the maternal plasma over the last week of gestation; foetal cortisol rises concurrently with, or even precedes, that of oestrone and oestradiol$17 \beta$, and dexamethasone or $\mathrm{ACTH}_{1-24}$ administered to foetuses after 100 days of gestation will induce premature delivery accompanied by the expected changes in maternal plasma progesterone and oestrogens (North, Hauser and First, 1973; Bosc, 1973).

Although there is evidence to support the view that the porcine placenta synthesizes steroids, the possibility that the endometrium also contributes to the production of steroids by the gravid uterus should not be ignored. In order to provide a more comprehensive picture of steroid synthesis by the uterus in late pregnancy, the metabolism of steroids by both the placenta and endometrium will be discussed.

\section{Uterine production of steroids in vivo}

Studies of the uterine secretion of progesterone and oestrogens during late gestation in the pig are relatively few although there is evidence that the umbilical venous concentration of progesterone is greater than that of the 
umbilical artery, which is consistent with intrauterine progesterone production (Godke and Day, 1973; Barnes, Comline and Silver, 1974; Silver et al., 1979; MacDonald et al., 1980). Evidence for an extra-ovarian source of oestrogens throughout gestation has been achieved by ovariectomizing sows in early pregnancy (the pregnancy being maintained by daily intramuscular injections of $300 \mathrm{mg}$ of progesterone) and determining the amount of oestrogens excreted into the urine (Fèvre, Léglise and Rombauts, 1968). By using this technique it was found that the excretion of urinary oestrogens by ovariectomized animals did not differ from intact animals throughout the course of gestation.

A modification of this method has been utilized in the present study to determine the output of steroids by the uterus in late pregnancy. Four gilts were ovariectomized at 98 days of gestation and catheters were inserted into the uterine artery and vein. Pregnancy was maintained by intramuscular injection of $10 \mathrm{mg}$ of medroxyprogesterone acetate every alternate day until 115 days post coitum (one day after the expected day of delivery) when the animals were killed. Daily paired samples were taken from the uterine artery and vein and the plasma concentration of progesterone, $17 \alpha$-hydroxyprogesterone, androstenedione and unconjugated oestrogens determined using specific radioimmunoassays. Medroxyprogesterone acetate did not cross-react in any of the assays used.

A positive venous - arterial $(\mathrm{V}-\mathrm{A})$ difference was obtained for all the steroids assayed. There was an apparent increase in uterine progesterone

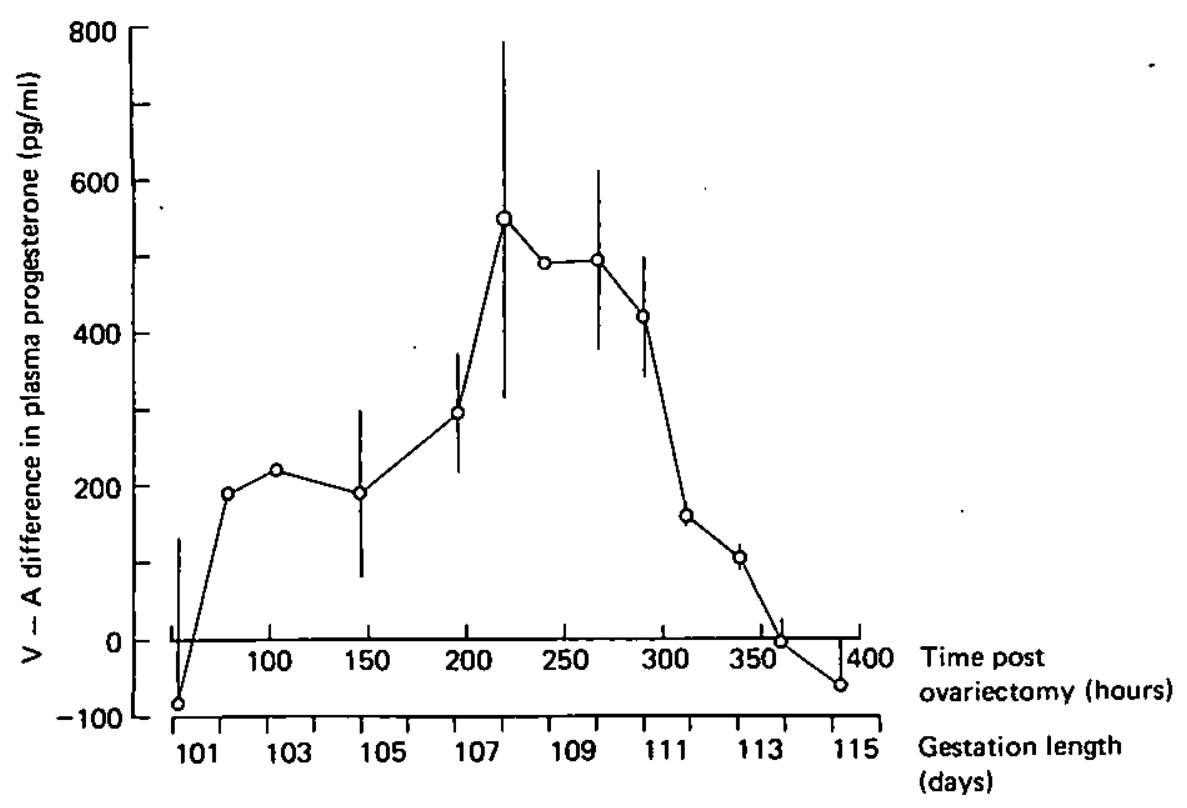

Figure 19.2 Uterine venous minus uterine arterial (V - A difference) plasma concentration of progesterone for gilts ovariectomized at 98 days post coitum in which pregnancy was maintained with medroxyprogesterone acetate. Each point represents the mean $\pm S . E . M . V-$ A difference expressed in pg/mi for up to four animals and is plotted against both the time in hours after ovariectomy and the length of gestation in days 
production between 104 days and 108 days post coitum with a peak $\mathrm{V}-\mathrm{A}$ difference of $500 \mathrm{pg} / \mathrm{ml}$ (Figure 19.2). Thereafter the venous concentration fell until, by the expected day of delivery (114 days post coitum), the VA difference had reached zero. The results obtained also demonstrated an increase in the output of $17 \alpha$-hydroxyprogesterone and androstenedione. In the case of androstenedione, this occurred from 108-110 days post coitum with a peak $\mathrm{V}-\mathrm{A}$ difference of $115 \mathrm{pg} / \mathrm{ml}$. In these animals a rise in the plasma concentration of unconjugated oestrogens occurred which was comparable to that obtained in intact animals thus indicating that the placenta or endometrium (or a combination of the two) is the major source of maternal circulating oestrogens in late pregnancy.

\section{Placental and endometrial metabolism of steroids in the pig; studies in vitro}

Histochemical evidence has been obtained for the presence of $\Delta^{5} 3 \beta$ - and $17 \beta$-hydroxysteroid dehydrogenases in placental tissue from the fourth week of gestation until term (Christie, 1968; Dufour and Raeside, 1969). Earlier studies by Bloch and Newman (1966) which demonstrated the conversion of dehydroepiandrosterone to androstenedione by porcine placental tissue obtained at the end of gestation also provide evidence for the presence of an active $\Delta^{5} 3 \beta$-hydroxysteroid dehydrogenase. An in vitro study of placental tissue taken in late pregnancy ( 112 days post coitum) revealed the presence of an active aromatase complex (Ainsworth and Ryan, 1966). Placental preparations were shown to convert $[7 \alpha$ $\left.{ }^{3} \mathrm{H}\right]$ dehydroepiandrosterone and $\left[4-{ }^{14} \mathrm{C}\right]$ androstenedione to oestrogens with oestrone being the major oestrogen formed. More recently, Choong and Raeside (1974) reported the presence of high concentrations of unconjugated and conjugated oestrogens in placental tissue and suggested that the placenta was the site of synthesis. High concentrations of unconjugated oestrogens have also been found in allantoic and amniotic fluid; Knight et al. (1977) showed that from 60-100 days the concentration of oestrone present in allantoic fluid increased from $0.9 \mathrm{ng} / \mathrm{ml}$ to $537.7 \mathrm{ng} /$ $\mathrm{ml}$, which greatly exceeds the concentration of oestrone in the maternal circulation and again indicates that the placenta is the probable site of synthesis. Although Ainsworth and Ryan (1966) demonstrated that the porcine placenta could utilize androgen substrates for oestrogen synthesis, no synthesis of oestrogens from either pregnenolone or progesterone could be detected by these authors. From these results it was concluded that the porcine placenta did not possess all the enzymes of the $\Delta^{4}$ pathway, in particular C-17,20-lyase, necessary for the conversion of pregnenolone to oestrogens. An outline of the enzymes of the $\Delta^{4}$ pathway which have been shown to be present in late pregnancy is given in Figure 19.3.

In vitro studies have demonstrated that both blastocyst (Gadsby and Heap, 1980) and endometrial tissue (Dueben et al., 1980) taken in early pregnancy are capable of synthesizing oestrogens from the C-21-precursors pregnenolone or progesterone respectively. However, relatively little is known about the metabolism of steroids by the placenta and endometrium in late gestation in the pig. In view of the accumulating evidence for the 
Pregnenolone

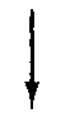

3ß-hydroxysteroid

dehydrogenase

Progesterone

i

$17 \alpha-\mathrm{OH}$ progesterone

1
1
1

Androstenedione

1

Oestrogens

Figure 19.3

The $\Delta^{4}-3$-keto pathway from pregnenolone to oestrogens. Enzymes whose presence has been confirmed by histochemical or in vitro incubation techniques are underlined.

placental synthesis of oestrogens, it was decided to re-examine the possibility that these tissues might be capable of synthesizing oestrogens from C-21 steroids. Furthermore, the metabolism of steroids by the endometrium in late pregnancy has not been studied extensively although there is some histochemical evidence that endometrial tissue possesses both $\Delta^{5} 3 \beta$ - and $17 \beta$-hydroxysteroid dehydrogenase activity (Christie, 1968; Dufour and Raeside, 1969). The enzyme $\Delta^{5} 3 \beta$-hydroxysteroid dehydrogenase occupies a key position in the synthesis of steroid hormones and its presence in endometrial tissue gives rise to the possibility that the endometrium may be able to synthesize progesterone from its immediate precursor, pregnenolone.

To determine which enzymes of the $\Delta^{4}$ pathway were present in the placenta and endometrium in late pregnancy, samples of these tissues were taken from gilts slaughtered at 100-112 days post coitum. Placental tissue obtained after both prostaglandin $F_{2 \alpha}$-induced and spontaneous delivery

Table 19.1 INTERMEDIATES OF THE $\triangle^{4}$ PATHWAY ISOLATED FROM INCUBATIONS OF PLACENTAL OR ENDOMETRIAL TISSUE OBTAINED AT 100 DAYS POST COITUM

\begin{tabular}{|c|c|c|c|c|}
\hline \multirow[t]{2}{*}{ Substrate } & \multirow[t]{2}{*}{ Product } & \multirow[t]{2}{*}{ Enzyme } & \multicolumn{2}{|r|}{ Tissue } \\
\hline & & & Placenta & Endometrium \\
\hline Pregnenolone & progesterone & 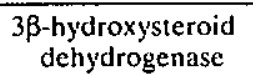 & $V$ & $V$ \\
\hline Progesterone & $\begin{array}{l}17 \alpha \text {-hydroxy } \\
\text { progesterone }\end{array}$ & $17 \alpha$-hydroxylase & $V$ & $x$ \\
\hline $\begin{array}{l}17 \alpha \text {-hydroxy } \\
\text { progesterone }\end{array}$ & androstenedione & C-17,20-lyase & $\checkmark$ & $x$ \\
\hline Androstenedione & oestrone & aromatase & V & $V$ \\
\hline
\end{tabular}

Tissues incubated with appropriate tritium-labelled precursor steroid in presence of excess co-factor. $\checkmark$ conversion demonstrated; $x$ conversion undetectable. 


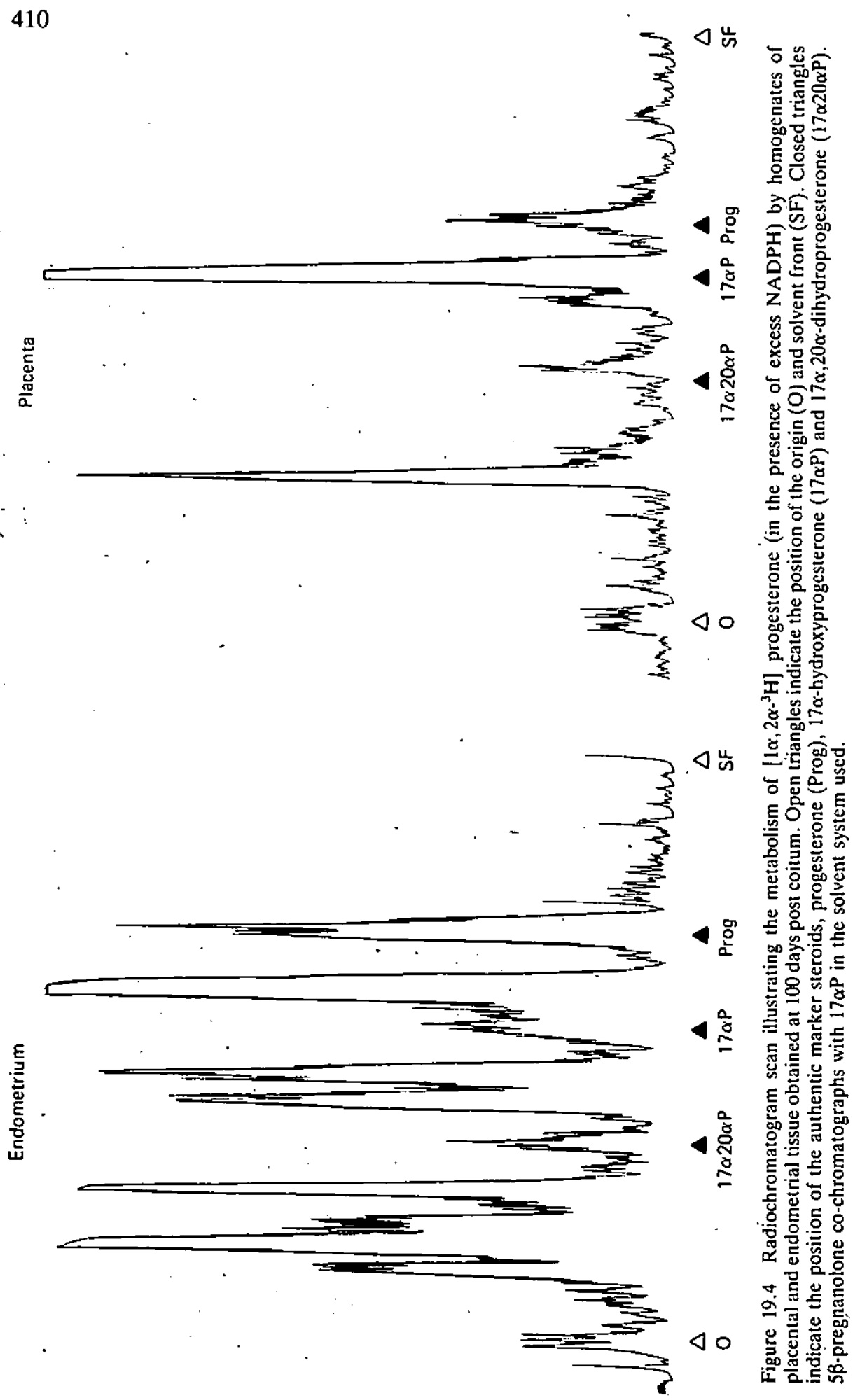




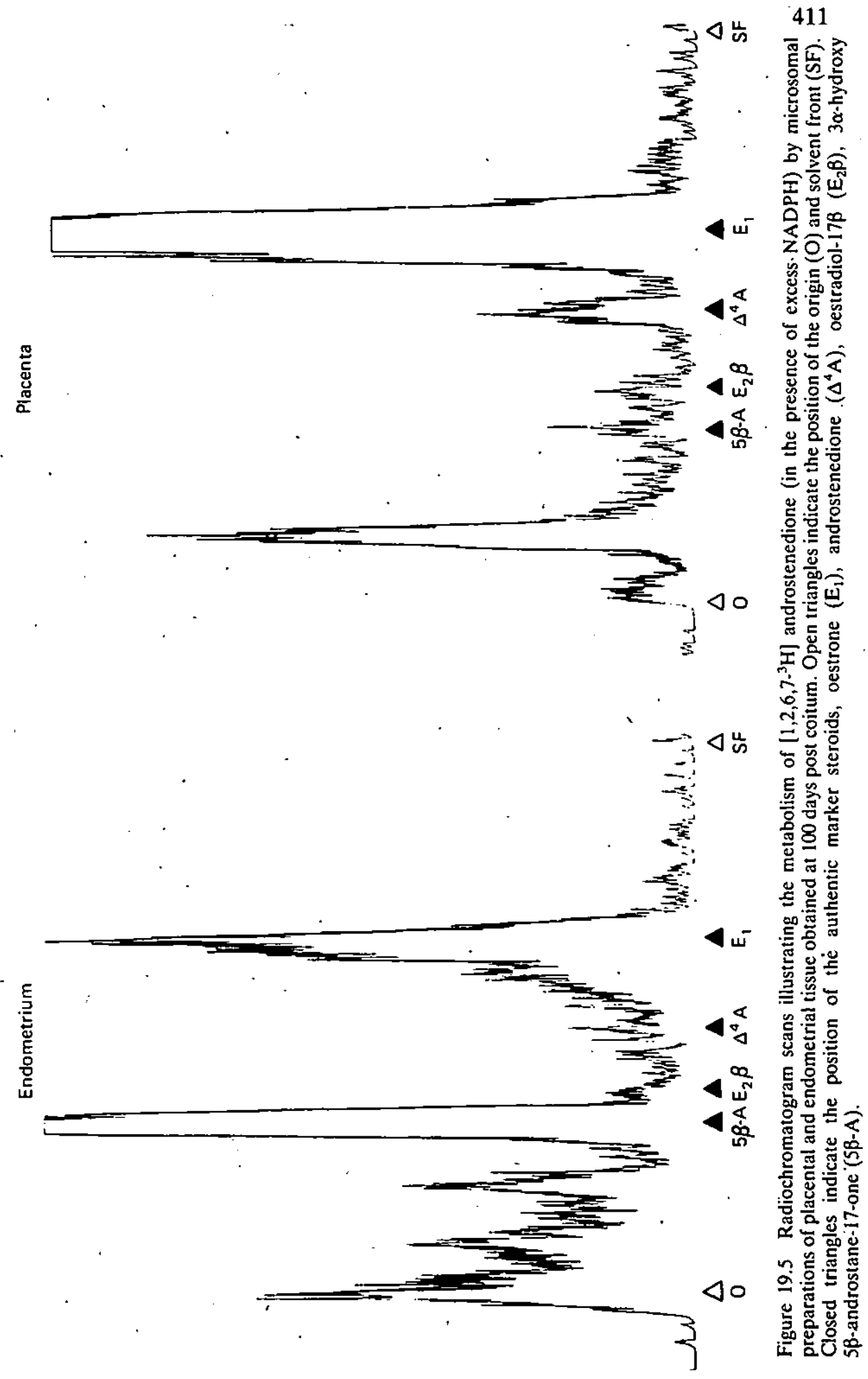


was also studied. Homogenates of the tissue were incubated with the following tritium-labelled precursors, $\left[7 \alpha-{ }^{3} \mathrm{H}\right]$ pregnenolone, $[1 \alpha, 2 \alpha-$ $\left.{ }^{3} \mathrm{H}\right]$ progesterone and $\left[7 \alpha^{3} \mathrm{H}\right] 17 \alpha$-hydroxyprogesterone in the presence of excess cofactor. Aromatase activity was determined by incubating microsomal preparations of the tissue with $\left[1,2,6,7-{ }^{3} \mathrm{H}\right]$ androstenedione. At the end of the incubation period the unconjugated metabolites were extracted from the medium with diethyl ether. These ether-soluble metabolites were then separated by thin layer chromatography and detected by using a radiochromatogram scanner. Identification of the metabolites was achieved by derivative formation and recrystallization with authentic carrier steroid to constant specific activity.

Table 19.1 indicates which enzymes of the $\Delta^{4}$ pathway were shown to be present in endometrial and placental tissue at 100 days post coitum. The major products of progesterone metabolism by the endometrium were $5 \beta$-reduced pregnanediols and pregnanetriols together with $5 \beta$-pregnan$3 \alpha$-ol-20-one ( $5 \beta$-pregnanolone). Less than $10 \%$ of the metabolites were $5 \alpha$-reduced. In contrast to this, the products of placental progesterone metabolism were predominantly $5 \alpha$ - and $5 \beta$-pregnanolones. $17 \alpha$ hydroxylated products accounted for less than $5 \%$ of the metabolites isolated (see Figure 19.4). The major product of androstenedione metabolism by placental tissue was oestrone, while the endometrium synthesized predominantly $5 \beta$-reduced androstanolones and $5 \beta$-androstanediols (see Figure 19.5).

\section{Changes in the activity of the enzymes of the $\Delta^{4}$ pathway before term}

\section{$\Delta^{5} 3 \beta$-hydroxysteroid dehydrogenase}

There was a decrease in the percentage of progesterone synthesized by placental tissue over the last two weeks of gestation while synthesis of progesterone by the endometrium showed little change. These findings contrast with the histochemical studies of Dufour and Raeside (1969) which suggested that a moderate increase in placental $\Delta^{5} 3 \beta$-hydroxysteroid dehydrogenase activity occurred near term and with those of Christie (1968) who found only trace activity of this enzyme from 101-112 days of pregnancy.

\section{$17 \alpha$-hydroxylase}

The two major products of progesterone metabolism by placental tissue obtained after spontaneous delivery at term (114 days post coitum) were $17 \alpha$-hydroxyprogesterone and $17 \alpha, 20 \alpha$-dihydroxy-4-pregnen-3-one $(17 \alpha, 20 \alpha$-progesterone). These two $17 \alpha$-hydroxylated metabolites accounted for $42 \%$ of the substrate added (see Table 19.2), with $50 \%$ of the radioactivity being associated with unmetabolized progesterone. These findings may represent an increase in $17 \alpha$-hydroxylase activity. An alternative explanation which needs to be investigated is the apparent loss of $5 \beta$-reductase activity, since no $5 \beta$ - reduced products were obtained by 


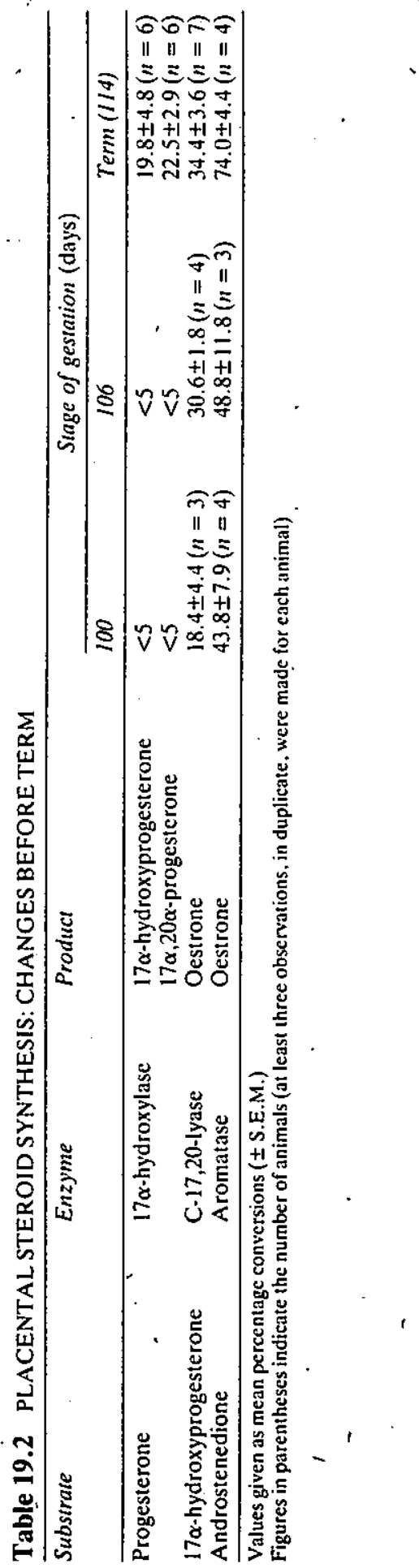




\section{4}

Placental steroid metabolism in late pregnancy

metabolism of progesterone by placental tissue obtained post delivery. Whether this loss of $5 \beta$-reductase activity occurred prior to delivery or was the result of anoxia arising from cessation of placental blood flow at term remains uncertain. No $17 \alpha$-hydroxyprogesterone could be isolated from incubations of endometrial tissue with progesterone at any of the stages of pregnancy studied.

\section{C-17,20-lyase}

Placental C-17,20-lyase activity as determined by conversion of $17 \alpha$ hydroxyprogesterone to oestrone was found to increase on or about day 105 post coitum. At 100 days post coitum conversion to oestrone was $18.5 \%$, by 106 days $30 \%$ and by the end of pregnancy had reached $30-35 \%$ (see Table 19.2). Conversion of $17 \alpha$-hydroxyprogesterone to oestrone by endometrial tissue remained at less than $3 \%$ throughout the last two weeks of gestation.

\section{Aromatase}

An increase in the activity of both placental (see Table 19.2) and endometrial aromatase was seen from 105-114 days post coitum. The increase in oestrone produced from androstenedione could, in part, be due to a decrease in the synthesis of $5 \beta$-reduced metabolites.

A composite diagram of the pathways of steroid metabolism present in vitro at 100 days and 114 days post coitum in both placental and endometrial tissue is given in Figure 19.6.

\section{Conclusions}

From the above studies, the following points may be made.

(a) Ovariectomy and medroxyprogesterone acetate replacement therapy allow the study of the uterine contribution to circulating steroids in late pregnancy. Using this technique, it has been demonstrated that the gravid uterus is capable of producing progesterone, $17 \alpha$ hydroxyprogesterone and androstenedione although the plasma concentration of these steroids is $5-10 \%$ that of intact, untreated animals. In contrast, plasma concentrations of unconjugated oestrogens were unchanged by ovariectomy thus providing further evidence for an extra-ovarian source of oestrogens in late pregnancy.

(b) In vitro investigations have demonstrated that both endometrial and placental tissue will actively metabolize steroids of the $\Delta^{4}$ pathway, although from these studies it would appear that only the placenta possesses all the enzymes necessary for the synthesis of oestrogens from pregnenolone by the $\Delta^{4}$ pathway. 
Endometrium

Pregnenolone

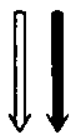

Progesterone

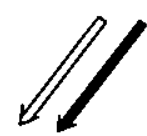

$5 \beta$-reduced $17 \alpha$-OH progesterone metabolites

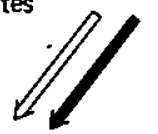

$5 \beta$-reduced metabolites

Androstenedione
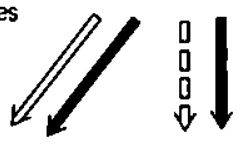

$5 \beta$-reduced Oestrone metabolites

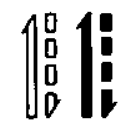

Oestradiol
Placenta

Pregnenolone

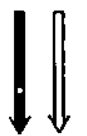

Progesterone

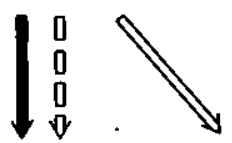

$17 \alpha-\mathrm{OH}$ progesterone $5 \beta$-reduced

metabolites
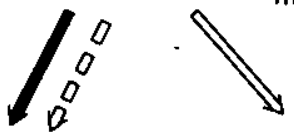

Androstenedione

$5 \beta$-reduced

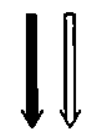

metabolites
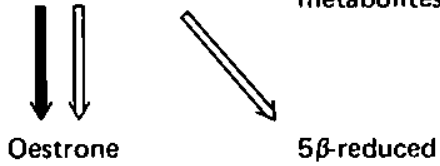

1010

matabolites

Oestradiol

Major pathway at 100 days post coitum

$\longrightarrow$ Major pathway at the end of gestation (114 days post coitum)

믐ㅁㄷㅇ $\Rightarrow$ Minor pathways

Figure 19.6 A composite diagram to illustrate the qualitative changes which occur in the metabolism of steroids of the $\Delta^{4}$ pathway by both placental and endometrial tissue between 100 days of gestation and term

(c) The apparent activity of placental $17 \alpha$-hydroxylase, C-17,20-lyase and aromatase increases between 100 days post coitum and term concurrent with the increase in maternal circulating oestrogens seen over this period.

Elevated foetal plasma cortisol concentrations at the end of pregnancy have been shown to influence the $\Delta^{4}-3$-keto pathway in both the sheep and the goat leading to an increase in placental oestrogen synthesis. Since the plasma cortisol concentration increases during the last two weeks of gestation in the foetal pig, at a time when the maternal plasma concentration of oestrogens is rising, it is possible that a similar mechanism may also operate in this species. 
There is, however, an important species difference in the role of oestradiol-17 $\beta$ in the control of parturition. Whereas in the goat the rising plasma concentration of oestradiol- $17 \beta$ plays an important role in controlling uterine prostaglandin $F_{2 \alpha}$ production and is therefore indirectly luteolytic, no such role for oestradiol- $17 \beta$ has been demonstrated in the control of parturition in the pig. Infusion of oestradiol-17 $\beta$ into the maternal circulation (Flint, Ricketts and Craig, 1979) or intramuscular injection of oestradiol-17 $\beta$ (Coggins, 1975; First and Bosc, 1979) in late pregnancy has no effect on the length of gestation. It may be postulated however that oestrogens play a facilitatory rather than obligatory role in the pig, possibly by raising the concentration of the myometrial oxytocin receptor and thereby preparing the uterus for oxytocin release during labour.

\section{Acknowledgements}

The author acknowledges the support of an M.R.C. studentship.

\section{References}

AINSWORTH, L.. and RYAN, K.J. (1966). Steroid hormone transformations by endocrine organs from pregnant mammals. I. Oestrogen biosynthesis by mammalian placental preparations in vitro. Endocrinology 79, 875-883

ANDERSON, A.B.M., FLINT, A.P.F. and TURNBULL, A.C. (1975). Mechanism of action of glucocorticoids in induction of ovine parturition: effect on placental steroid metabolism. J. Endocr. 66, 61-70

ASH, R.W. and HEAP, R.B. (1975). Oestrogen, progesterone and corticosteroid concentration in peripheral plasma of sows during pregnancy, parturition, lactation and after weaning. $J$. Endocr. 64, 141-154

ASH, R.W., BANKS, P., BAILES, G., BROAD, S. and HEAP, R.B. (1973). Plasma oestrogen, progesterone and corticoid concentrations in the pregnant, parturient and lactating sow. J. Reprod. Fert. 33, 359-360

BALDWIN, D.M. and STABENFELDT, G.H. (1975). Endocrine changes in the pig during late pregnancy, parturition and lactation. Biol. Reprod. 12, 508-515

BARNES, R.J., COMLINE, R.S. and SILVER, M. (1974). Foetal and maternal progesterone concentrations in the pig. $J$. Endocr. 62, 419-420

BLOCH, E. and NEWMAN, E. (1966). Comparative placental steroid synthesis. I. Conversion of $\left(7-{ }^{3} \mathrm{H}\right)$-dehydroepiandrosterone to $\left({ }^{3} \mathrm{H}\right)$-androst-4-ene 3,17-dione. Endocrinology 79, 524-530

BOSC, M.J. (1973). Modification de la durée de gestation de la Truie après administration d'ACTH aux foetus. C. r. hebd. Seanc. Acad. Sci., Paris 276, 3183

CHOONG, C.H. and RAESIDE, J.I. (1974). Chemical determination of oestrogen distribution in the foetus and placenta of the domestic pig. Acta endocr. 77, 171-185

CHRISTIE, G.A. (1968). Distribution of hydroxysteroid dehydrogenase in the placenta of the pig. J. Endocr. 40, 285-291 
COGGINS, E.G. (1975). Mechanisms controlling parturition in swine. PhD Thesis. University of Wisconsin, Madison, USA

CURRIE, W.B. and THORBURN, G.D. (1977). The foetal role in timing the initiation of parturition in the goat. In The Fetus and Birth, pp. 49-72. Amsterdam, Elsevier/Excerpta Medica/North Holland

CURRIE, W.B., COX, R.I. and THORBURN, G.D. (1976). Release of prostaglan$\operatorname{din} F$, regression of corpora lutea and induction of premature parturition in goats treated with oestradiol-17ß. Prostaglandins 12, 1093-1103

DUEBEN, B.D., WISE, T.H., BAZER, F.W., FIELDS, M.J. and KALRA, P.S. (1980). Metabolism of $\mathrm{H}^{3}$-progesterone to estrogens by pregnant gilt endometrium and conceptus. J. Anim. Sci. 49, Suppl. 1, 293(Abstract 375)

DUFOUR, J. and RAESIDE, J.I. (1969). Hydroxysteroid dehydrogenase activity in the placenta of the domestic pig. Endocrinology 84, 426-431

FÈVRE, J., LÉGLISE, P.-C and ROMBAUTS, P. (1968). Du rôle de l'hypophyse et des ovaires dans la biosynthese des oestrogènes aux cours de la gestation chez la truie. Annls Biol. anim. Biochim. Biophys. 8, 225-233

FIRST, N.L. and BOSC, M.J. (1979). Proposed mechanisms controlling parturition and the induction of parturition in swine. J. Anim. Sci. 48, 1407-1421

FLINT, A.P.F. and RICKETTS, A.P. (1979). Control of placental endocrine function: role of enzyme activation in the onset of labour. J. Steroid Biochem. 11, 493-500

FLINT, A.P.F., RICKETTS, A.P. and CRAIG, V.A. (1979). The control of placental steroid synthesis at parturition in domestic animals. Anim. Reprod. Sci. 2, 239-251

FLINT, A.P.F., KINGSTON, E.J., ROBINSON, J.S. and THORBURN, G.D. (1978). Initiation of parturition in the goat: evidence for control by foetal glucocorticoid through activation of placental $C_{21}$-steroid $17 \alpha$ hydroxylase. J. Endocr. 78, 367-378

GADSBY, J.E. and HEAP, R.B. (1980). Oestrogen synthesis by embryos of the pig, cow and sheep. J. Anim. Sci. 49, Suppl. 1, 299 (Abstract 389)

GODKE, R.A. and DAY, B.N. (1973). Maternal and fetal plasma progestin levels in swine. J. Anim. Sci. 37, 313

KNIGHT, 3.W., BAZER, F.W., THATCHER, W.W., FRANK, D.E. and WALLACE, M.D. (1977). Conceptus development in intact and unilaterally hysterectomized and ovariectomized gilts: inter-relations among hormonal status, placental development, fetal fluids and fetal growth. J. Anim. Sci. 44, 620-637

MACDONALD, A.A., COLENBRANDER, B., El_SAESSER, F. and HEILHECKER, A. (1980). Progesterone production by the pig fetus and the response to stimulation by adrenocorticotrophin. J. Endocr. 85, 34P

NARA, B.S. and FIRST, N.L. (1977). Effect of indomethacin and PGF $2 \alpha$ on porcine parturition. J. Anim. Sci. 45, Suppl. 1, 191

NORTH, S.A., HAUSER, E.R. and FIRST, N.L. (1973). Induction of parturition in swine and rabbits with the corticosteroid dexamethasone. J. Anim. Sci. 36, 1170-1174

ROBERTSON, H.A. and KING, G.J. (1974). Plasma concentrations of progesterone oestrone, oestradiol-17 $\beta$ and oestrone sulphate in the pig at implantation during pregnancy and at parturition. J. Reprod. Fert. 40, 133-141 


\section{Placental steroid metabolism in late pregnancy}

SILVER, M., BARNES, R.J., COMLINE, R.S., FOWDEN, A.L., CLOVER, L. and MITCHELL, M.D. (1979). Prostaglandins in the foetal pig and prepartum endocrine changes in mother and foetus. Anim. Reprod. Sci. 2, 305-322

STEELE, P.A., FLINT, A.P.F. and TURNBULL, A.C. (1976). Increased uteroovarian androstenedione production before parturition in sheep. $J$. Reprod. Fert. 46, 443-445 